Vol. 2, No. 2, 2019

\author{
О. Р. Рідка ${ }^{1}$, В. С. Матійчук ${ }^{2}$, І. Б. Собечко ${ }^{1}$, В. В. Сергесв ${ }^{1}$, Н. І. Тищенко ${ }^{3}$ \\ ${ }^{1}$ Національний університет “Львівська політехніка”, кафедра фізичної аналітичної та загальної хімії \\ ${ }^{2}$ Львівський національний університет імені Івана Франка, кафедра органічної хімії \\ ${ }^{3}$ Інститут проблем матеріалознавства ім. І.М. Францевича НАНУ, відділ фізико-хімії і технології \\ наноструктурної кераміки та нанокомпозитів \\ phys.chem.lp@gmail.com
}

\title{
ТЕРМОДИНАМІЧНІ ВЛАСТИВОСТІ МЕТИЛ 6-МЕТИЛ-2-ОКСО-4- ФЕНІЛ-1,2,3,4-ТЕТРАГІДРОПІРИМІДИН-5-КАРБОКСИЛАТУ ТА ЙОГО РОЗЧИНІВ В ЕТИЛАЦЕТАТІ І БЕНЗОЛІ ТА ЇХ СУМІШАХ
}

https://doi.org/10.23939/ctas2019.02.012

За експериментально визначеною температурною залежністю розчинності метил-6метил-2-оксо-4-арил-1,2,3,4-тетрагідропіримідин-5-карбонової кислоти в етилацетаті, бензолі та їх сумішах пораховано величини енталыпії та ентропії розчинення. Значення ентальпій та ентропій змішування за 298 К пораховані 3 врахуванням енталыпій та ентропій плавлення, визначених за даними дериватографічного методу аналізу та перерахованих до 298 К. Показано вплив розчинників та їх сумішей на розчинність та ентальпії і ентропії змішування. Встановлено присутність компенсаційного ефекту процесу змішування за 298 К.

Ключові слова: метиловий естер 6-метил-2-оксо-4-арил-1,2,3,4-тетрагідропіримідин-5карбонової кислоти; ентальпія і ентропія розчинення, змішування, плавлення.

\section{Вступ}

Необхідність синтезу шестичленних гетероциклічних сполук, котрі містять один або декілька гетероатомів азоту, зумовлена широким спектром їх застосування у різних галузях промисловості. Так, однією з основних вимог застосування речовин у харчовій та фармацевтичній промисловості $€$ використання особливо чистих речовин. Зазвичай процеси синтезу та очищення твердих речовин відбуваються за участі індивідуальних розчинників або їх сумішей, тому оптимізація цих процесів є неможливою без визначення термодинамічних параметрів їх розчинення. В останні роки з'явилося багато робіт [1-6] 3 визначення термодинамічних властивостей розчинності сполук у ряді індивідуальних розчинників та їхніх сумішей. Представлена робота $\epsilon$ однією з таких. Ї̈і метою є дослідження термодинамічних властивостей розчинності метил 6-метил-2-оксо-4-феніл-1,2,3,4-тетрагідро-піримідин5-карбоксилата, який проявляє широкий спектр біологічної активності [7] в органічних розчинниках різної полярності та їхніх сумішей.

Матеріали та методи досліджень

Метил 6-метил-2-оксо-4-феніл-1,2,3,4-тетрагідро-піримідин-5-карбоксилат, структурну формулу якого наведено на рис. 1, отримували взаємодією 0,05 моль бензойного альдегіду, 0,05 моль карбаміду та 0,075 моль метилового естеру ацетооцтової кислоти в середовищі етанолу за присутності концентрованої хлоридної кислоти. Після кипятіння упродовж 3 годин реакційну суміш охолоджували до 273 К та залишали до повної кристалізації речовини у вигляді осаду. Осад відфільтровували та двічі перекристалізовували з етанолу. Вихід основного продукту становив $83 \%$.<smiles>COC(=O)C1=C(C)NC(=O)NC1c1ccccc1</smiles>

Рис. 1. Структурна формула метил 6-метил-2-оксо-4-феніл-1,2,3,4тетрагідропіримідин-5-карбоксилату

Ідентифікацію метил 6-метил-2-оксо-4феніл-1,2,3,4-тетрагідропіримідин-5-карбонової кислоти проводили за результатами ЯМР спектроскопії 3 використанням ЯМР спектрофо- 
Термодинамічні властивості метил 6-метил-2-оксо-4-феніл-1,2,3,4-тетрагідропіримідин-5-карбоксилату...

тометра Varian 400 (400 МГц). Розчинником слугував ДМCO-D6. Спектр ЯМР ${ }^{1} \mathrm{H} \delta: 2,25(\mathrm{c}$, $3 \mathrm{H}, \mathrm{CH} 3), 3,53(\mathrm{c}, 3 \mathrm{H}, \mathrm{CH} 3), 5,14(\mathrm{c}, 1 \mathrm{H}, \mathrm{CH}), 7,20$ 7,35 (м, 5H, Ph), 7,75 (c,1H, NH), 9,22 (c,1H, NH).

Чистоту речовини визначали хроматографічно, використовуючи Agilent 1100 HPLC, який обладнаний мас-селективним детектором на колоні Zorbax SB-C18, $4.6 \mathrm{~mm} \times 15 \mathrm{~mm}$ та діодною матрицею, елюент А ацетонітрил-вода 3 0,1\% TFA (95:5). Чистота речовини становить 99,9\%.

Дослідження розчинності метил 6-метил-2оксо-4-феніл-1,2,3,4-тетрагідро-піримідин-5-карбоксилата проводили в органічних багатотоннажних розчинниках, а саме у бензолі, етилацетаті та їхніх сумішах. Перед застосуванням розчинники піддавали очистці методами перекристалізації та фракційної перегонки 3 подальшою їх ідентифікацією за температурою кипіння $\left(T_{b o i l}\right)$ та показником заломлення $\left(n_{D}{ }^{20}\right)$ табл.1.

\section{Табличя 1}

\section{Фізико-хімічні властивості розчинників}

\begin{tabular}{|c|c|c|c|c|}
\hline \multirow{2}{*}{ Розчинник } & \multicolumn{2}{|c|}{$T_{\text {boil }}{ }^{\circ} \mathrm{C}$} & \multicolumn{2}{c|}{$n_{D}^{20}$} \\
\cline { 2 - 5 } & експ. & літ. [8] & експ. & літ. [8] \\
\hline Бензол & 79,8 & 80,1 & 1,5014 & 1,5017 \\
\hline Етилацетат & 76,9 & 77,1 & 1,3723 & 1,3724 \\
\hline
\end{tabular}

Чистоту розчинників підтверджували методом газорідинної хроматографії, вміст основного компонента складав 99,8\%мас.

Розчинення метил 6-метил-2-оксо-4-феніл1,2,3,4-тетрагідропіримідин-5-карбоксилату здійснювали в герметичній скляній колбі з мішалкою, зворотним холодильником, термометром та патрубком для відбору проб. Температуру води в термостаті підтримували 3 точністю $\pm 0,1$ К. Насичення розчинів проводили не менше ніж 48 год за постійного перемішування (швидкість обертання мішалки - 60-70 об/хв) за температури досліду. Досліди проводили в режимах як підвищення, так і пониження температури. Відсутність петлі гістерезису на кривій температурної залежності розчинності підтвердило досягнення стану, близького до рівноваги.

Проби розчинів відбирали серіями $32-3$ зразків 3 використанням попередньо зважених герметичних бюксів, 3 подальшим видаленням розчинника при 343 К. Зважування на всіх етапах здійснювали 3 використанням ваг ВЛР-200 3 точністю $\pm 0,0002$ г.

Термогравіметричні дослідження проводили з використанням дериватографа "Q-1500 D” системи Paulik- Paulik-Erday в динамічному режимі в атмосфері повітря зі швидкістю нагріву 5 град/хв, 3 використанням платинового тиглю (рис. 2).

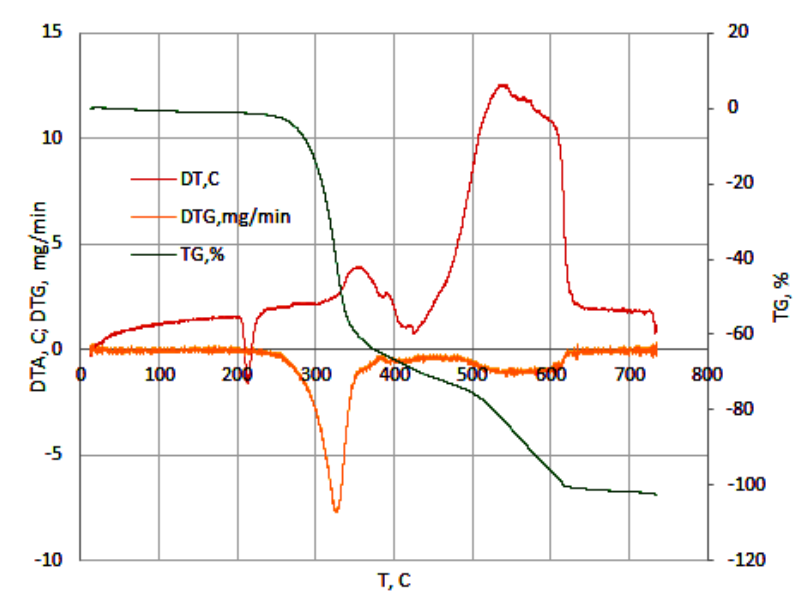

Рис. 2. Дериватограма метил 6-метил-2-оксо-4феніл-1,2,3,4-тетрагідропіримідин-5-карбоксилата

\section{Результати досліджень та їх обговорення}

Результати експериментального визначення температурної залежності розчинності метил 6-метил-2-оксо-4-феніл-1,2,3,4-тетрагідропіримідин-5-карбонової кислоти, виражені у мольних частках $\left(x_{p . p .}\right)$ в етилацетаті та бензолі наведено в табл. 2, а у суміші розчинників - у

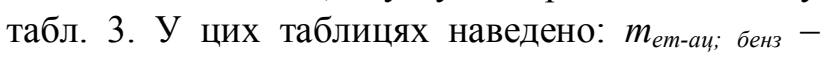
маси розчинників; $m_{p . p .}$ - маси розчиненої речовини; $T$ - температуру, за якої визначено розчинність.

Таблиия 2

Температурна залежність розчинності метил 6-метил-2-оксо-4-феніл-1,2,3,4тетрагідропіримідин-5-карбоксилату в органічних розчинниках

\begin{tabular}{|c|c|c|c|}
\hline$T, \mathrm{~K}$ & $\mathrm{~m}_{\text {ет-ац; бенз }}, \Gamma$ & $m_{p . p}, \Gamma$ & $x_{p . p .} \cdot 10^{3}$ \\
\hline 1 & 2 & 3 & 4 \\
\hline \multicolumn{4}{|c|}{ етилацетат } \\
\hline 287,4 & 1,8880 & 0,0059 & 1,13 \\
\hline 287,4 & 1,9373 & 0,0061 & 1,13 \\
\hline 287,4 & 2,1058 & 0,0065 & 1,10 \\
\hline
\end{tabular}


О. Р. Рідка, В. С. Матійчук, І. Б. Собечко, В. В. Сергеєв, Н. І. Тищенко

Продовження табл. 2

Закінчення табл. 2

\begin{tabular}{|c|c|c|c|}
\hline 1 & 2 & 3 & 4 \\
\hline 293,1 & 1,7869 & 0,0068 & 1,37 \\
\hline 293,1 & 1,7935 & 0,0069 & 1,37 \\
\hline 293,1 & 1,5755 & 0,0060 & 1,36 \\
\hline 294,5 & 1,6400 & 0,0064 & 1,39 \\
\hline 294,5 & 1,6019 & 0,0062 & 1,39 \\
\hline 295,7 & 1,4007 & 0,0056 & 1,43 \\
\hline 295,7 & 1,4763 & 0,0059 & 1,43 \\
\hline 295,7 & 1,8191 & 0,0072 & 1,43 \\
\hline 297,0 & 1,4321 & 0,0063 & 1,57 \\
\hline 297,0 & 1,9290 & 0,0080 & 1,49 \\
\hline 297,0 & 2,2603 & 0,0096 & 1,53 \\
\hline 299,7 & 1,8957 & 0,0087 & 1,65 \\
\hline 299,7 & 2,0251 & 0,0094 & 1,66 \\
\hline 299,7 & 1,8796 & 0,0091 & 1,73 \\
\hline 300,5 & 1,8458 & 0,0085 & 1,65 \\
\hline 300,5 & 1,7961 & 0,0083 & 1,66 \\
\hline 300,5 & 1,9838 & 0,0095 & 1,72 \\
\hline 304,0 & 1,7614 & 0,0090 & 1,84 \\
\hline 304,0 & 1,9394 & 0,0101 & 1,86 \\
\hline 304,0 & 1,8286 & 0,0094 & 1,85 \\
\hline 310,0 & 1,4350 & 0,0091 & 2,28 \\
\hline 310,0 & 1,7691 & 0,0108 & 2,19 \\
\hline 310,0 & 1,8278 & 0,0112 & 2,19 \\
\hline 318,5 & 1,9247 & 0,0150 & 2,78 \\
\hline 318,5 & 1,6604 & 0,0128 & 2,76 \\
\hline 318,5 & 1,6084 & 0,0126 & 2,81 \\
\hline 322,5 & 1,7528 & 0,0162 & 3,30 \\
\hline 322,5 & 1,8757 & 0,0174 & 3,31 \\
\hline 322,5 & 1,8084 & 0,0167 & 3,29 \\
\hline 328,8 & 1,7557 & 0,0201 & 4,09 \\
\hline 328,8 & 1,8986 & 0,0210 & 3,94 \\
\hline 328,8 & 1,7600 & 0,0199 & 4,03 \\
\hline 331,8 & 1,9000 & 0,0228 & 4,28 \\
\hline 331,8 & 1,8428 & 0,0224 & 4,33 \\
\hline 331,8 & 1,5117 & 0,0182 & 4,29 \\
\hline $\ln \mathrm{N}_{2}=(3,25 \pm 0,2)-(2892 \pm 63) * 1 / \mathrm{T} ; \mathrm{R}=0,99$ \\
\hline & & & \\
\hline 287,0 & 1,7425 & 0,0008 & 0,146 \\
\hline 287,0 & 1,5928 & 0,0007 & 0,14 \\
\hline 287,0 & 1,5960 & 0,0007 & 0,139 \\
\hline 290,6 & 1,7123 & 0,0009 & 0,167 \\
\hline 290,6 & 1,7819 & 0,0009 & 0,16 \\
\hline 290,6 & 2,0803 & 0,0011 & 0,168 \\
\hline 296,6 & 1,9529 & 0,0014 & 0,219 \\
\hline 296,6 & 1,5504 & 0,0011 & 0,215 \\
\hline 301,5 & 1,6340 & 0,0014 & 0,272 \\
\hline 301,5 & 1,4398 & 0,0012 & 0,265 \\
\hline 301,5 & 1,5552 & 0,0013 & 0,265 \\
\hline 304,8 & 1,8806 & 0,0018 & 0,304 \\
\hline 304,8 & 1,4263 & 0,0014 & 0,312 \\
\hline & & \multicolumn{2}{|c|}{} \\
\hline
\end{tabular}

\begin{tabular}{|c|c|c|c|}
\hline 1 & 2 & 3 & 4 \\
\hline 304,8 & 1,6060 & 0,0016 & 0,316 \\
\hline 307,2 & 2,1231 & 0,0024 & 0,359 \\
\hline 307,2 & 1,5540 & 0,0018 & 0,357 \\
\hline 307,2 & 1,8044 & 0,0020 & 0,352 \\
\hline 309,5 & 1,8715 & 0,0022 & 0,373 \\
\hline 309,5 & 1,6515 & 0,0019 & 0,365 \\
\hline 309,5 & 1,5129 & 0,0018 & 0,378 \\
\hline 312,0 & 5,0495 & 0,0068 & 0,427 \\
\hline 312,0 & 2,1277 & 0,0028 & 0,418 \\
\hline 312,0 & 1,6152 & 0,0021 & 0,413 \\
\hline 314,3 & 2,1714 & 0,0031 & 0,453 \\
\hline 314,3 & 1,6452 & 0,0024 & 0,463 \\
\hline 314,3 & 2,0896 & 0,0029 & 0,44 \\
\hline 318,0 & 1,9254 & 0,0034 & 0,552 \\
\hline 318,0 & 1,5995 & 0,0028 & 0,556 \\
\hline 318,0 & 1,5768 & 0,0027 & 0,543 \\
\hline 323,4 & 1,7894 & 0,0036 & 0,638 \\
\hline 323,4 & 1,7686 & 0,0036 & 0,646 \\
\hline 323,4 & 1,8853 & 0,0038 & 0,64 \\
\hline 328,6 & 2,0198 & 0,0050 & 0,785 \\
\hline 328,6 & 1,7676 & 0,0044 & 0,79 \\
\hline 328,6 & 1,6108 & 0,0040 & 0,788 \\
\hline 331,3 & 1,8565 & 0,0050 & 0,854 \\
\hline 331,3 & 1,7808 & 0,0050 & 0,882 \\
\hline 331,3 & 1,7415 & 0,0048 & 0,865 \\
\hline 334,7 & 1,9977 & 0,0064 & 1,016 \\
\hline 334,7 & 1,5389 & 0,0049 & 1,01 \\
\hline 334,7 & 1,7372 & 0,0056 & 1,023 \\
\hline $\ln \mathrm{N}_{2}=(4,85 \pm 0,16)-(3940 \pm 50) * 1 / \mathrm{T}, \mathrm{R}=0,99$ \\
\hline
\end{tabular}

Таблиия 3

Температурна залежність розчинності метил 6-метил-2-оксо-4-феніл-1,2,3,4тетрагідропіримідин-5-карбоксилату в суміші етилацетат:бензол

\begin{tabular}{|c|c|c|c|c|}
\hline$T, \mathrm{~K}$ & $m_{\text {ет-аи, }} \Gamma$ & $m_{\text {бенз, }}$ Г & $m_{p . p}, \Gamma$ & $x_{p . p} \cdot 10^{3}$ \\
\hline 1 & 2 & 3 & 4 & 5 \\
\hline \multicolumn{5}{|c|}{ етилаиетат (75):бензол (25)* } \\
\hline 283,0 & 1,9220 & 0,6407 & 0,0062 & 0,839 \\
\hline 283,0 & 1,3320 & 0,4440 & 0,0047 & 0,918 \\
\hline 283,0 & 2,2860 & 0,7620 & 0,0082 & 0,933 \\
\hline 289,3 & 2,0627 & 0,6876 & 0,0086 & 1,084 \\
\hline 289,3 & 2,1778 & 0,7259 & 0,0089 & 1,063 \\
\hline 289,3 & 2,0388 & 0,6796 & 0,0082 & 1,046 \\
\hline 292,6 & 2,1725 & 0,7242 & 0,0104 & 1,239 \\
\hline 292,6 & 2,1837 & 0,7279 & 0,0102 & 1,214 \\
\hline 292,6 & 2,2068 & 0,7356 & 0,0103 & 1,213 \\
\hline 298,0 & 1,9994 & 0,6665 & 0,0104 & 1,346 \\
\hline 298,0 & 1,4337 & 0,4779 & 0,0081 & 1,459 \\
\hline \multicolumn{5}{|c|}{}
\end{tabular}


Термодинамічні властивості метил 6-метил-2-оксо-4-феніл-1,2,3,4-тетрагідропіримідин-5-карбоксилату...

Продовження табл. 3

Продовження табл. 3

\begin{tabular}{|c|c|c|c|c|c|c|c|c|c|}
\hline 1 & 2 & 3 & 4 & 5 & 1 & 2 & 3 & 4 & 5 \\
\hline 298,0 & 2,1188 & 0,7063 & 0,0124 & 1,515 & 302,5 & 1,3954 & 1,3954 & 0,0091 & 1,096 \\
\hline 303,5 & 2,0338 & 0,6779 & 0,0127 & 1,623 & 308,2 & 1,3439 & 1,3439 & 0,0099 & 1,238 \\
\hline 303,5 & 2,1106 & 0,7035 & 0,0131 & 1,613 & 308,2 & 1,4584 & 1,4584 & 0,0109 & 1,256 \\
\hline 303,5 & 2,1593 & 0,7198 & 0,0136 & 1,631 & 308,2 & 1,4434 & 1,4434 & 0,0106 & 1,234 \\
\hline 304,6 & 2,1636 & 0,7212 & 0,0142 & 1,705 & 313,5 & 1,3444 & 1,3444 & 0,0126 & 1,575 \\
\hline 304,6 & 2,3315 & 0,7772 & 0,0152 & 1,694 & 313,5 & 1,3614 & 1,3614 & 0,0131 & 1,617 \\
\hline 304,6 & 2,1788 & 0,7263 & 0,0149 & 1,777 & 313,5 & 1,3853 & 1,3853 & 0,0134 & 1,625 \\
\hline 308,0 & 2,2259 & 0,7420 & 0,0162 & 1,885 & 317,5 & 1,2094 & 1,2094 & 0,0124 & 1,723 \\
\hline 308,0 & 2,2310 & 0,7437 & 0,0161 & 1,869 & 317,5 & 1,3803 & 1,3803 & 0,0143 & 1,741 \\
\hline 308,0 & 2,2636 & 0,7545 & 0,0176 & 2,020 & 317,5 & 1,4123 & 1,4123 & 0,0152 & 1,808 \\
\hline 314,0 & 2,2138 & 0,7379 & 0,0197 & 2,305 & 320,8 & 1,3891 & 1,3891 & 0,0162 & 1,959 \\
\hline 314,0 & 2,2179 & 0,7393 & 0,0198 & 2,318 & 320,8 & 1,3538 & 1,3538 & 0,0158 & 1,96 \\
\hline 314,0 & 2,2645 & 0,7548 & 0,0201 & 2,305 & 320,8 & 1,3722 & 1,3722 & 0,0160 & 1,959 \\
\hline 317,7 & 2,1210 & 0,7070 & 0,0217 & 2,650 & 325,2 & 1,3411 & 1,3411 & 0,0185 & 2,31 \\
\hline 317,7 & 2,2185 & 0,7395 & 0,0227 & 2,656 & 325,2 & 1,4267 & 1,4267 & 0,0190 & 2,231 \\
\hline 317,7 & 2,2190 & 0,7397 & 0,0227 & 2,650 & 325,2 & 1,4821 & 1,4821 & 0,0205 & 2,323 \\
\hline 323,0 & 2,1525 & 0,7175 & 0,0247 & 2,972 & 329,0 & 1,3785 & 1,3785 & 0,0205 & 2,497 \\
\hline 323,0 & 2,2238 & 0,7413 & 0,0244 & 2,848 & 329,0 & 1,4443 & 1,4443 & 0,0215 & 2,499 \\
\hline 323,0 & 2,2322 & 0,7441 & 0,0256 & 2,976 & 329,0 & 1,4445 & 1,4445 & 0,0219 & 2,545 \\
\hline 327,5 & 2,1382 & 0,7127 & 0,0290 & 3,518 & 332,4 & 1,3327 & 1,3327 & 0,0220 & 2,771 \\
\hline 327,5 & 2,2143 & 0,7381 & 0,0293 & 3,427 & 332,4 & 1,3788 & 1,3788 & 0,0231 & 2,812 \\
\hline 327,5 & 2,2396 & 0,7465 & 0,0303 & 3,509 & 332,4 & 1,4350 & 1,4350 & 0,0239 & 2,795 \\
\hline 333,5 & 2,1188 & 0,7063 & 0,0316 & 3,867 & \multicolumn{5}{|c|}{$\ln \mathrm{N}_{2}=(3,84 \pm 0,17)-(3230 \pm 53)^{*} 1 / \mathrm{T} ; \mathrm{R}=0,99$} \\
\hline 333,5 & 2,1593 & 0,7198 & 0,0316 & 3,795 & \multicolumn{5}{|c|}{ етилацетат (25):бензол (75)* } \\
\hline 333,5 & 2,1344 & 0,7115 & 0,0316 & 3,839 & 283,0 & 0,7707 & 2,3120 & 0,0028 & 0,297 \\
\hline \multicolumn{5}{|c|}{$\ln \mathrm{N}_{2}=(2,86 \pm 0,24)-(2803 \pm 75) * 1 / \mathrm{T} ; \mathrm{R}=0,99$} & 283,0 & 0,8403 & 2,5208 & 0,0031 & 0,301 \\
\hline \multicolumn{5}{|c|}{ етилачетат (50):бензол (50)* } & 283,0 & 0,7970 & 2,3910 & 0,0031 & 0,318 \\
\hline 283,4 & 1,5013 & 1,5013 & 0,0046 & 0,515 & 289,3 & 0,7576 & 2,2728 & 0,0039 & 0,42 \\
\hline 283,4 & 1,5264 & 1,5264 & 0,0045 & 0,496 & 289,3 & 0,7773 & 2,3318 & 0,0043 & 0,452 \\
\hline 283,4 & 1,5299 & 1,5299 & 0,0047 & 0,517 & 289,3 & 0,8525 & 2,5575 & 0,0046 & 0,436 \\
\hline 286,0 & 1,3140 & 1,3140 & 0,0043 & 0,55 & 292,6 & 0,8386 & 2,5157 & 0,0051 & 0,497 \\
\hline 286,0 & 1,4126 & 1,4126 & 0,0048 & 0,572 & 292,6 & 0,8483 & 2,5448 & 0,0054 & 0,515 \\
\hline 286,0 & 1,0051 & 1,0051 & 0,0033 & 0,552 & 292,6 & 0,8529 & 2,5586 & 0,0051 & 0,488 \\
\hline 289,2 & 1,4165 & 1,4165 & 0,0058 & 0,689 & 298,0 & 0,7394 & 2,2182 & 0,0050 & 0,552 \\
\hline 289,2 & 1,3646 & 1,3646 & 0,0055 & 0,678 & 298,0 & 0,8496 & 2,5487 & 0,0064 & 0,61 \\
\hline 289,2 & 1,3822 & 1,3822 & 0,0057 & 0,694 & 298,0 & 0,8104 & 2,4312 & 0,0054 & 0,544 \\
\hline 292,5 & 1,3238 & 1,3238 & 0,0061 & 0,775 & 304,6 & 0,8756 & 2,6268 & 0,0091 & 0,848 \\
\hline 292,5 & 1,4541 & 1,4541 & 0,0067 & 0,775 & 304,6 & 0,8636 & 2,5909 & 0,0088 & 0,827 \\
\hline 292,5 & 1,4549 & 1,4549 & 0,0065 & 0,751 & 304,6 & 0,8664 & 2,5991 & 0,0086 & 0,806 \\
\hline 295,1 & 1,4604 & 1,4604 & 0,0073 & 0,841 & 308,0 & 0,8728 & 2,6183 & 0,0092 & 0,856 \\
\hline 295,1 & 1,3821 & 1,3821 & 0,0068 & 0,827 & 308,0 & 0,8723 & 2,6169 & 0,0090 & 0,838 \\
\hline 295,1 & 1,4288 & 1,4288 & 0,0071 & 0,836 & 308,0 & 0,8728 & 2,6184 & 0,0094 & 0,874 \\
\hline 298,0 & 1,1913 & 1,1913 & 0,0063 & 0,882 & 314,0 & 0,8545 & 2,5635 & 0,0120 & 1,141 \\
\hline 298,0 & 1,4083 & 1,4083 & 0,0076 & 0,907 & 314,0 & 0,8510 & 2,5529 & 0,0108 & 1,031 \\
\hline 298,0 & 1,3962 & 1,3962 & 0,0074 & 0,891 & 314,0 & 0,8717 & 2,6151 & 0,0113 & 1,058 \\
\hline 299,3 & 1,4449 & 1,4449 & 0,0083 & 0,966 & 317,7 & 0,8673 & 2,6020 & 0,0125 & 1,143 \\
\hline 299,3 & 1,4182 & 1,4182 & 0,0078 & 0,925 & 317,7 & 0,8680 & 2,6039 & 0,0131 & 1,232 \\
\hline 299,3 & 1,4384 & 1,4384 & 0,0082 & 0,959 & 317,7 & 0,8329 & 2,4987 & 0,0129 & 1,264 \\
\hline 302,5 & 1,3628 & 1,3628 & 0,0087 & 1,073 & 323,0 & 0,8716 & 2,6149 & 0,0158 & 1,474 \\
\hline 302,5 & 1,4394 & 1,4394 & 0,0093 & 1,08 & 323,0 & 0,8820 & 2,6459 & 0,0163 & 1,508 \\
\hline
\end{tabular}




\begin{tabular}{|c|c|c|c|c|}
\hline 1 & 2 & 3 & 4 & 5 \\
\hline 323,0 & 0,8618 & 2,5855 & 0,0151 & 1,429 \\
\hline 327,5 & 0,8633 & 2,5899 & 0,0174 & 1,644 \\
\hline 327,5 & 0,8705 & 2,6114 & 0,0166 & 1,556 \\
\hline 327,5 & 0,8549 & 2,5648 & 0,0170 & 1,622 \\
\hline 333,1 & 0,8349 & 2,5046 & 0,0208 & 2,031 \\
\hline 333,1 & 0,8290 & 2,4870 & 0,0210 & 2,065 \\
\hline 333,1 & 0,3412 & 1,0235 & 0,0089 & 2,127 \\
\hline 335,5 & 0,8195 & 2,4586 & 0,0208 & 2,064 \\
\hline 335,5 & 0,8467 & 2,5400 & 0,0230 & 2,214 \\
\hline 335,5 & 0,8576 & 2,5727 & 0,0220 & 2,092 \\
\hline \multicolumn{5}{|c|}{$\ln \mathrm{N}_{2}=(4,11 \pm 0,32)-(3438 \pm 98) * 1 / \mathrm{T} ; \mathrm{R}=0,99$} \\
\hline \multicolumn{5}{|c}{}
\end{tabular}

* Співвідношення етилацетат:бензол, \% мас.

Також у табл. 2 та 3 наведено лінійні рівняння $\ln x_{2}=\Delta_{\text {sol }} S / R-\Delta_{\text {sol }} H /(R \cdot T)$, отримані в результаті обробки експериментальних даних; де: $\Delta_{\text {sol }} S$ - зміна ентропії в процесі розчинення $\Delta_{\text {sol }} H$ - диференційна теплота розчинення. Тут і далі вибіркові дисперсії величин, отримані в результаті обробки експериментальних даних методом найменших квадратів, представлені 3 урахуванням коефіцієнта Стьюдента 3 рівнем значимості 0,95 .

Термодинамічні параметри розчинності $\Delta_{\text {sol }} H$ i $\Delta_{\text {sol }} S$ можна представити сумою відповідних параметрів фазового переходу кристалічного метил 6-метил-2-оксо-4-феніл-1,2,3,4тетрагідропіримідин-5-карбоксилата в рідку фазу 3 параметрами їх змішування з розчинником чи їх сумішшю ( рівняння 1,2 ).

$$
\begin{gathered}
\Delta_{\text {sol }} H=\Delta_{f u s} H+\Delta_{\text {mix }} H \\
\text { та } \Delta_{\text {sol }} S=\Delta_{f u s} S+\Delta_{\text {mix }} S
\end{gathered}
$$

Для визначення зміни ентальпії $\left(\Delta_{m i x} H\right)$ i ентропії $\left(\Delta_{m i x} \mathrm{~S}\right)$ змішування необхідно враховувати величину ентальпії $\left(\Delta_{f u s} H\right)$ і ентропії $\left(\Delta_{f u s} S\right)$ плавлення метил 6-метил-2-оксо-4-феніл1,2,3,4-тетрагідропіримідин-5-карбоксилата при середній температурі дослідів 3 визначення їх розчинності. Величини ентальпій та ентропій плавлення при температурі плавлення, визначені в попередній роботі [9] та уточнені тепер, становлять: $\quad \Delta_{f u s} H_{487,7}=32,9 \pm 1,7 \quad$ кДж/моль; $\Delta_{f u s} S_{487,7}=67,5 \pm 2,0$ Дж/(мольК).

Середніми температурами дослідів 3 визначення розчинності є 309-310 К, які є близькими до загальноприйнятої 298 К, тому, нами було прийнято рішення розрахувати термодинамічны параметри плавлення та змішування при 298 К.
Термодинамічні параметри розчинності метил 6-метил-2-оксо-4-феніл-1,2,3,4тетрагідропіримідин-5-карбоксилату в органічних розчинниках

та їх сумішах за $298 \kappa$.

\begin{tabular}{|c|c|c|c|c|}
\hline \multirow{2}{*}{ Розч. } & \multicolumn{1}{|c|}{$\Delta_{\text {sol }} H$} & $\Delta_{\text {mix }} H$ & $\Delta_{\text {sol }} S$ & $\Delta_{\text {mix }} S$ \\
\cline { 2 - 5 } & \multicolumn{2}{|c|}{ кДж/моль } & \multicolumn{2}{|c|}{ Дж/моль· $\mathrm{K}$} \\
\hline етилач. & $24,05 \pm 0,53$ & $0,7 \pm 2,0$ & $27,0 \pm 1,7$ & $-15,1 \pm 4,3$ \\
\hline бензол & $32,76 \pm 0,42$ & $9,4 \pm 1,9$ & $40,3 \pm 1,3$ & $-2,6 \pm 2,5$ \\
\hline $75: 25^{*}$ & $23,30 \pm 0,62$ & $-0,1 \pm 1,9$ & $23,8 \pm 2,0$ & $-19,1 \pm 2,9$ \\
\hline $50: 50^{*}$ & $26,85 \pm 0,44$ & $3,4 \pm 1,9$ & $31,9 \pm 1,4$ & $-11,0 \pm 2,5$ \\
\hline $25: 75^{*}$ & $28,58 \pm 0,81$ & $5,2 \pm 2,0$ & $34,2 \pm 2,7$ & $-8,7 \pm 3,4$ \\
\hline
\end{tabular}

*співвідношення етилацетат:бензол, \% мас.

Величину ентальпії та ентропії плавлення досліджуваної речовини перераховували до $298 \mathrm{~K}$ за рівняннями, наведеними у роботі [10,11]: $\quad \Delta_{\text {fus }} H_{298}=23,4 \quad \pm 1,8 \quad$ кДж/моль, $\Delta_{\text {fus }} S_{298}=32,9 \pm 2,1$ Дж/мольК. У табл. 4 наведено термодинамічні параметри розчинності досліджуваної сполуки за $298 \mathrm{~K}$, розраховані за рівняннями 1 та 2, позитивні або близькі до 0 в межах похибок експерименту та розрахунків свідчать, що на руйнування міжмолекулярних зв'язків в індивідуальних речовинах потрібні більші витрати енергії, ніж виділяється в результаті утворенні нових міжмолекулярних зв'язків у досліджуваних системах.

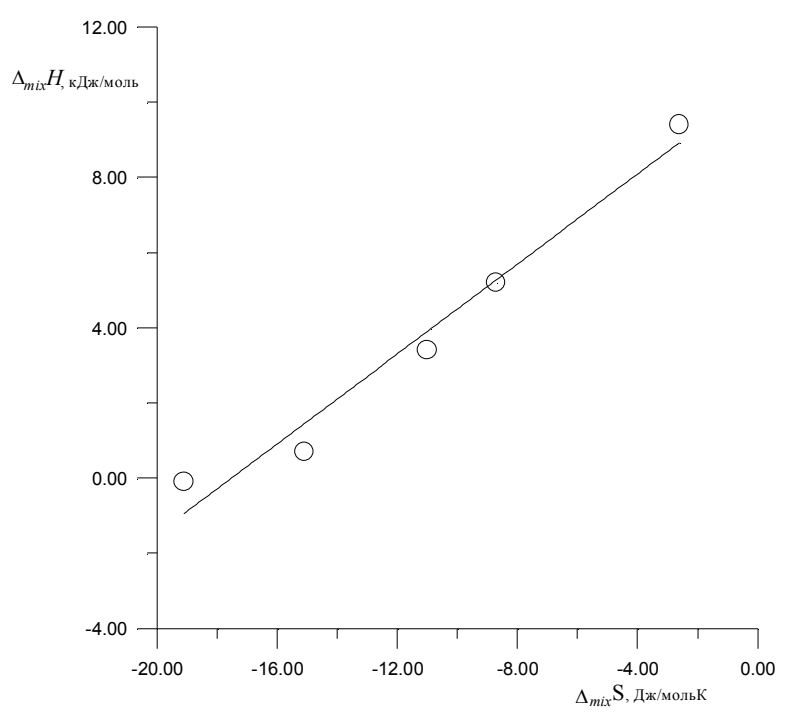

Рис. 2. Залежність між ентальпією та ентропією змімування метил 6-метил-2-оксо-4-феніл-1,2,3,4тетрагідропіримідин-5-карбоксилату в етилацетаті та бензолі та їх сумішах 
Термодинамічні властивості метил 6-метил-2-оксо-4-феніл-1,2,3,4-тетрагідропіримідин-5-карбоксилату...

Також нам вдалось встановити присутність компенсаційного ефекту процесу змішування метил 6-метил-2-оксо-4-феніл-1,2,3,4-тетрагідропіримідин-5-карбоксилату з етилацетатом, бензолом та їх сумішами (рис. 2), рівняння 3 .

$$
\Delta_{m i x} H_{298}=0,598 \cdot \Delta_{m i x} S_{298}+10,48 \text {. }
$$

\section{Висновок}

У результаті проведених досліджень визначено термодинамічні властивості розчинності для метил 6-метил-2-оксо-4-феніл-1,2,3,4тетрагідропіримідин-5-кар-боксилату в органічних розчинниках різної полярності та їх сумішах. Отримані експериментальні та розрахункові дані можуть бути використані для оптимізації процесів очищення та розділення, прогнозування реакційної поведінки речовини у розчині.

\section{Література}

1. Tianhua Huang, Dingqiang Lu, Xiuquan Ling, Xinxian Wang, Tongqi Liu, Fangfang Shen, Kefei He. (2017). Thermodynamic models for determination of the solid-liquid equilibrium of istradefylline in ethyl acetate plus (isopropanol, tetrahydrofuran, acetone) binary solvent mixtures. J. Chem. Thermodynamics. 111. 31-40. doi: 10.1016/j.jct.2017.03.015

2. Huan Shen, Songgu Wu, Yumin Liu, Kangli Li., Shijie Xu, Junbo Gong. (2017). Determination and correlation of Avermectin B1a solubility in different binary solvent mixtures at temperatures from (283.15 to 313.15) K. J. Chem Thermodynamics. 105. 253-266. doi: 10.1016/j.jct.2016.10.022

3. Jinxiu Wang, Chuang Xie, Qiuxiang Yin, Linggang Tao, Jun Lv, Yongli Wang, ... Hongxun Hao. (2016). Measurement and correlation of solubility of cefmenoxime hydrochloride in pure solvents and binary solvent mixtures. J. Chem Thermodynamics. 95. 63-71. doi: 10.1016/j.jct.2015.11.024

4. Zhengyang Han, Hongxun Hao, HaoWu, Qi Liu, Shuyi Zong, Xin Huang. (2019). Solubility and thermodynamic properties of dirithromycin form $\mathrm{A}$ and form B in pure solvents and binary solvent mixture. $J$. Chem Thermodynamics. 132. 240-249. doi: 10.1016/j.jct.2018.12.044

5. Yüfang Wu, Jiangwei Gao, Suyue Yan, Chenmeng Wu, Bin Hu. (2019) The dissolution behavior and apparent thermodynamic analysis of temozolomide in pure and mixed solvents. J. Chem Thermodynamics. 132. 240-249. doi: 10.1016/j.jct.2018.11.026

6. JiaxinWu, RenjieXu, XinYuan, JiaZhao JianWang. (2019). Equilibrium solubility of dinitolmide in several neat solvents and binary aqueous co-solvent mixtures: Experimental determination and thermodynamic analysis. J. Chem Thermodynamics. 132. 373382. . doi: 10.1016/j.jct.2019.01.013

7. Sandhu S., Sandhu J. (2012). Past, present and future of the Biginelli reaction: a critical perspective. ARKATUSA, 1(i), 66-130. doi: 10.3998/ark.5550190.0013.103.

8. Chemistry Web-book [Електронний ресурс]. Режим доступу: http://webbook.nist.gov.

9. Рідка О. Р., Матійчук В.С., Собечко І. Б., Кочубей В. В., Сергеєв В. В. (2017). Термодинамічні властивості метил-6-метил-2-оксо-4-феніл-1,2,3,4тетрагідропіримідин-5-карбоксилату в органічних розчинниках. Вісник Начіонального університету “Львівська політехніка". 868. 57-61.

10. Собечко И. Б., Прокоп Р. Т., Горак Ю. И. и др. Термодинамические характеристики растворения 1-метил-2-пирролкарбоновой кислоты в органических растворителях Вопросы химии и химической технологии. 2013. 4. 12-15.

11. Собечко И. Б., Ван-Чин-Сян Ю. Я., Кочубей В. В. и др. Термодинамические свойства фуран-2карбоновой и 3-(2-фурил)-2-пропеновой кислот Журнал физической химии. 2014. Т. 88. 12. С. 1885-1892.

O. R. Ridka ${ }^{1}$, V. S. Matiychuk ${ }^{2}$, I. B. Sobechko ${ }^{3}$, V. V. Serheyev ${ }^{4}$, N. I. Tishchenko ${ }^{5}$

${ }^{1}$ Lviv Polytechnic National University, Department of Physical Analytical and General Chemistry

${ }^{2}$ Franko National University of Lviv, Department of Organic Chemistry

${ }^{3}$ The Institute of Materials Science. I.M. Frantsevich NASU, Department of Physical Chemistry and Technology of Nanostructured Ceramics and Nanocomposites

\section{THERMODYNAMIC PROPERTIES OF METHYL ESTER OF 6-METHYL-2-OXO-4-ARYL-1,2,3,4- TETRAHIDROPIRYMIDYN-5-CARBOXYLATE IN ETHYLACETATE AND BENZENE AND THEIR MIXTURE}

From the temperature dependence of the solubility of methyl ester of 6-methyl-2-oxo-4-aryl-1,2,3,4tetrahidropirymidyn-5-carboxylic acid in ethyl acetate, benzene and their mixture dissolution enthalpies and entropies were determined. Enthalpies and entropies of mixing at $298 \mathrm{~K}$ were calculated using enthalpies and entropies of fusion determined by differential-thermal-analysis and adjusted to $298 \mathrm{~K}$. The influence of solvent on the solubility and magnitude of the enthalpy and entropy of mixing at $298 \mathrm{~K}$ was shown. Compensatory effect of mixing process at $298 \mathrm{~K}$ were determined.

Key words: methyl 6-methyl-2-oxo-4-aryl-1,2,3,4-tetrahidropirymidyn-5-carboxylate; enthalpy and entropy of dissolution, mixing, fusion. 